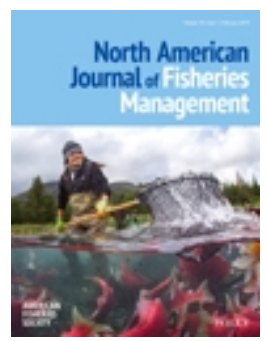

\title{
Growth dynamics of invasive Blue Catfish in four subestuaries of the Chesapeake Bay, USA
}

\begin{tabular}{|r|l|}
\hline Journal: & North American Journal of Fisheries Management \\
\hline Manuscript ID & UJFM-2020-0001.R1 \\
\hline Manuscript Type: & Special Section \\
\hline Keywords: & $\begin{array}{l}\text { Age and Growth, Life History, Mixed Models, Non-Indigenous Species, } \\
\text { Spatiotemporal Variability }\end{array}$ \\
\hline In Press, August 9, 2020
\end{tabular}

\section{SCHOLARONE" Manuscripts}


1 Suggested Running Head: Invasive Blue Catfish Growth Dynamics

2

3 Growth dynamics of invasive Blue Catfish in four subestuaries of the Chesapeake Bay, USA

4 Corbin D. Hilling* hillingc5@gmail.com

5 Department of Fish and Wildlife Conservation, Virginia Polytechnic Institute and State

6 University, 310 West Campus Drive, Cheatham Hall, Room 100, Blacksburg, Virginia 24061, 7 USA

8

$9 \quad$ Yan Jiao

10 Department of Fish and Wildlife Conservation, Virginia Polytechnic Institute and State

11 University, 310 West Campus Drive, Cheatham Hall, Room 100, Blacksburg, Virginia 24061, 12 USA

14 Aaron J. Bunch

15 Virginia Department of Game and Inland Fisheries, 3801 John Tyler Memorial Highway, 16 Charles City, Virginia 23030, USA

17

Robert S. Greenlee

19 Virginia Department of Game and Inland Fisheries, 3801 John Tyler Memorial Highway, 20 Charles City, Virginia 23030, USA

21

22 Joseph D. Schmitt ${ }^{1}$

23 Department of Fish and Wildlife Conservation, Virginia Polytechnic Institute and State

24 University, 310 West Campus Drive, Cheatham Hall, Room 100, Blacksburg, Virginia 24061, 25 USA

27 Donald J. Orth

28 Department of Fish and Wildlife Conservation, Virginia Polytechnic Institute and State 29 University, 310 West Campus Drive, Cheatham Hall, Room 100, Blacksburg, Virginia 24061, 30 USA

${ }^{1}$ Present Address: U.S. Geological Survey, Lake Erie Biological Station, 6100 Columbus Avenue Sandusky, $\mathrm{OH} 44870$ 
Biological invasions occur as a multi-stage process and life history traits can change during the invasion process. Blue Catfish Ictalurus furcatus were introduced in three Virginia tidal tributaries of the Chesapeake Bay in the 1970s and 1980s, but have expanded their range to almost all large tributaries of the Bay. Understanding the species' growth is important to understand impacts on other resident species and population dynamics. Virginia Blue Catfish exhibited wide variability in individual growth, prompting testing of six alternative hypotheses (similar growth across space and time, as well as variable growth by: river systems, sampling years, cohorts and both river systems and time) on its growth dynamics within four Virginia tidal rivers (James, Mattaponi, Pamunkey, and Rappahannock) over the period 2002-2016. Blue Catfish growth in Virginia was best explained by a model considering cohort and river as random effects. The Rappahannock River was the first in Virginia to receive Blue Catfish and had slower growth than other systems during the observation period. Growth rates declined for

$<\mathrm{A}>$ Introduction strategies (Feiner et al. 2012). Newly introduced invaders or individuals at the invasion front tend to grow faster than those from previously established populations and can invest more energy in growth than reproduction (Bøhn et al. 2004; Brandner et al. 2013; Azour et al. 2015; Kornis et al. 2017). Individual growth is an important life history trait to understand population biology of fishes. Growth parameters are related to other life history traits (e.g., natural mortality and reproductive characteristics; Jensen 1996) and affect vulnerability to predation and fisheries

57 (Kerns and Lombardi-Carlson 2017). Growth rates of fishes are influenced by activity level, 58 population density and environmental conditions, including food availability, food quality, and environmental factors such as temperature (Kitchell et al. 1977; Jones 1986; Jenkins et al. 1999; 
attributed to differences in intraspecific competition, adaptive selection, or epigenetic changes (Prentis et al. 2008; Phillips et al. 2010; Richards et al. 2012; Liebl et al. 2013; Azour et al. 2015; Masson et al. 2016). However, few studies of non-native species' life history feature long time series or large spatial ranges (e.g., Tarkan et al. 2012; Copp et al. 2016), thus understanding spatial, temporal, and environmental factors may provide insights for ecology and management of widespread or established invaders.

Blue Catfish Ictalurus furcatus are native to many large North American rivers of the Gulf of Mexico drainages, but have been widely introduced beyond their native range in the United States to provide fishing opportunities (Greenlee and Lim 2011; Schloesser et al. 2011). Consequently, the species now ranges from California to the Atlantic coast states from Florida to New Jersey (Fuller and Neilson 2019). Studies on non-native Blue Catfish have reported high abundances (Fabrizio et al. 2018), low natural mortality rates (Hilling et al. 2018), reductions in native species' abundances (Bonvechio et al. 2011b; Homer and Jennings 2011; Schloesser et al. 2011), and predation on at-risk and economically important species (Moran et al. 2016; Aguilar et al. 2017; Schmitt et al. 2017, 2019a). However, Jennings et al. (2018) found diets were dominated by Asian clams Corbicula fluminea and reported that Blue Catfish were unlikely to harm sportfish communities. Life history traits of Blue Catfish can be exceptionally plastic including food habits (Schmitt et al. 2019b), growth rates (Boxrucker and Kuklinski 2006), and movement patterns (Tripp et al. 2011; Tuckey et al. 2017). Further, this freshwater species has been noted to tolerate relatively high salinities with records in Chesapeake Bay in water as saline as $21.8 \mathrm{psu}$ and can thrive in estuaries (Fabrizio et al. 2018; Nepal and Fabrizio 2019). More research on life history traits across the non-native range of Blue Catfish is needed. For example, the food habits of this species are size-dependent, where the prevalence of fish in the diet increases with Blue Catfish size (Schloesser et al. 2011; Schmitt et al. 2017, 2019a, 2019b). Studies on individual growth dynamics over space and time can help managers prioritize control efforts to areas where fish quickly or regularly reach sizes conducive to predation on species of economic and ecological importance (e.g., blue crab Callinectes sapidus and Alosa spp.).

Studies suggest that while native Blue Catfish populations exhibit fast individual growth (Graham 1999), fish from non-native populations can grow exceptionally fast (Bonvechio et al. 2011b; Greenlee and Lim 2011). Further, Blue Catfish have exhibited highly variable growth in 
Virginia subestuaries of Chesapeake Bay (Greenlee and Lim 2011). Many studies on growth of invasive species have compared growth of native and non-native populations with mixed results (Kwak et al. 2006; Sakaris et al. 2006; Rypel 2014; Copp et al. 2016; Massie et al. 2018). These mixed results may stem from temporal differences in growth as populations progress through the process of invasion. The primary objective of this study was to evaluate how growth variability is partitioned over space and time for an established invader. With an incomplete 15-year time series of length-at-age observations, we examined growth of non-native Blue Catfish in four rivers with different introduction histories. We evaluated six candidate models to improve our understanding of growth variability, based on alternative hypotheses (Table 1) of growth similarity over space and time, as well as differences over space, time, and space and time. We hypothesized Blue Catfish growth would decline over time as the species became established. Further, we assessed whether patterns in mean length-at-age were synchronous among river systems. Another objective was to assess growth over time in comparison to native and nonnative populations to determine if inferences changed depending on which point in time was used for comparisons. We expected growth would be faster than most populations early in the time series, but closer to average as populations matured. We expand upon previous work by Greenlee and Lim (2011) as we add eight years to the time series, examine growth variability from a model selection approach, examine synchrony among rivers, and compare to other populations. Other previous work examining growth rates in Virginia tributaries of Chesapeake Bay have ignored spatial differences (Hilling et al. 2018) or focused on age-0 fish (Nepal and Fabrizio 2020).

\section{$<\mathrm{A}>$ Methods}

Study area.-The Chesapeake Bay estuary is the largest in the United States and supports numerous recreational and commercial fisheries, providing economic benefits to the region (Houde 2006). However, nutrient pollution, heavy fishing pressure, habitat alteration, and disease contributed to fishery collapses throughout the 1900s (Houde 2006; Schulte 2017). Introductions of Blue Catfish in Virginia subestuaries of the Chesapeake Bay began in 1974 in the Rappahannock River to provide new fisheries and later in the James (1975) and Mattaponi (1985) rivers (Figure 1, Jenkins and Burkhead 1994). In the late 1980s, the species presumably colonized the Pamunkey River from the Mattaponi River via their confluence that forms the 
121 York River, which ultimately flows into Chesapeake Bay. After stockings ceased in the 1980s,

122 these populations showed a prolonged period of invasion reaching highest densities in the mid-

123 late 2000s (Orth et al. 2017; Bunch et al. 2018). Over the course of the invasion, individuals have

124 expanded to many other Chesapeake Bay tributaries in Virginia and Maryland (Schloesser et al.

125 2011; Bunch et al. 2018; Nepal and Fabrizio 2019).

126 Data collection.-We analyzed length-at-age data collected by Virginia Department of Game 127 and Inland Fisheries (VDGIF) from 2002 to 2016 to examine trends and variability in Blue 128 Catfish individual growth in the James, Mattaponi, Pamunkey, and Rappahannock rivers. 129 Personnel from VDGIF collected Blue Catfish using low-frequency electrofishing or high130 frequency electrofishing to monitor populations and collect biological data. All electrofishing was conducted using a Smith-Root 9.0 GPP boat-mounted electrofishing unit. Low-frequency electrofishing (15 pulses/sec, 340 or $680 \mathrm{~V}$ ) was used to sample catfishes from late July to early September in some years, but usually entirely in August to avoid reduced gear efficiency at lower temperatures (Bodine and Shoup 2010). Fixed sampling sites were selected using a modified-predator approach to target areas where large Blue Catfish were known to exist (Vokoun and Rabeni 1999; Greenlee and Lim 2011). River bends associated with large drop offs were selected for fixed sites as early surveys suggested they were preferred habitat for large Blue Catfish. Sites selected were generally within the freshwater to oligohaline sections of these tidal rivers, but salinities during sampling were as high as $11.8 \mathrm{psu}$. Sites were sampled from 2002 to 2016 for age information with not all rivers and sampling sites within rivers sampled annually. Some sites were not sampled in all years due to reduced effectiveness of sampling gear due to low $(<100 \mu \mathrm{S} / \mathrm{cm})$ or high conductivity $(>18,000 \mu \mathrm{S} / \mathrm{cm})$. A new electrofishing unit was used in 2014 collections that was prone to overloading when salinity exceeded approximately 2 psu. The original electrofishing units were repaired for use in 2016 to avoid conductivity issues. High frequency electrofishing (60-120 pulses/sec, 340-680 V) within the same time frames supplemented low-frequency collections from the Rappahannock River, providing additional large fish (Table 2$)$. The total length $\left(L_{T}, \mathrm{~mm}\right)$ of captured fish was measured and lapillar otoliths were extracted to estimate ages (Long and Stewart 2010). A subsampling procedure was used to reduce the number of fish within size groups for age analysis. Biologists randomly selected fish from two size groups $<600 \mathrm{~mm}$ and fish $\geq 600 \mathrm{~mm}$ at each sampling site to reduce sample sizes to a manageable number for laboratory procedures given high abundances of Blue Catfish in 
these systems (Bunch et al. 2018; Fabrizio et al. 2018). A random subsample of fish $<600 \mathrm{~mm}$ (generally $n=30$ ) were sacrificed per site, as well as 25 to $100 \%$ of fish $\geq 600 \mathrm{~mm}$, depending on how many large fish were collected in an individual sampling run. The purpose of this subsampling procedure was to ensure large individuals were well-represented in the sample due to observed growth variability (Greenlee and Lim 2011). Otoliths were processed via the protocol developed by (Buckmeier et al. 2002) with modifications described by Greenlee and Lim (2011). We calculated the year class for all aged fish using assigned ages and collection year.

Data analysis. - We examined growth dynamics in Virginia Blue Catfish using both growth modeling in an information theoretic framework and hypothesis testing based on length-at-age observations. We extended the von Bertalanffy growth function (VBGF) to nonlinear mixed effect models to examine Blue Catfish growth during over a 15-year period in Virginia's tidal rivers during the establishment and expansion phases of the invasion. Nonlinear mixed effects models feature fixed and random effects with nonlinear parameters of the underlying model. We used the three-parameter version of the von Bertalanffy growth function (Quinn and Deriso 1999; Haddon 2011). Because variance in length-at-age increases with age, we assumed lengthat-age $\left(L_{\mathrm{t}}\right)$ followed a multiplicative error structure (i.e., the natural logarithm of the model produces normally-distributed, additive errors) as

$$
L_{t}=L_{\infty}\left(1-e^{-k\left(t-t_{0}\right)}\right) e^{\varepsilon}, \varepsilon \sim N\left(0, \sigma^{2}\right) \text {, }
$$

where $L_{\infty}$ is the average maximum length, $k$ is the Brody growth coefficient describing how quickly $L_{\infty}$ is reached, $t$ is the age, and $t_{0}$ is the theoretical age when length is zero, and $\sigma^{2}$ is the variance of the model residuals which are assumed to follow a normal distribution (Quinn and Deriso 1999; Haddon 2011). We estimated $L_{\infty}$ on a $\log _{\mathrm{e}}$-scale to reduce the scale differences among parameters to ease model convergence.

The VBGF as presented above can be extended to nonlinear mixed effect models to incorporate variability over space and time (Ma et al. 2017). We used random effects to describe growth within cohorts, sampling years, and rivers (Vincenzi et al. 2014), providing a convenient methodology to efficiently estimate parameters that vary among numerous years and locations. Further, preliminary exploration of the dataset suggested differences in growth exist among 
181

182

183

184 185

186

187

188

189

190

191

192

193

194

195

196

197

198

199

200

201

202

203

204

205

206

207

208

209

210

cohorts through time. Length-at-age observations from single collection years show unusual growth patterns due to seemingly faster growing older cohorts. The inclusion of random effects in modeling efforts permitted grouping of correlated length-at-age observations. Further, this provided an opportunity to develop multiple hypotheses and candidate models to explain growth within and among these populations over time.

We developed six alternative hypotheses and corresponding models to better understand the patterns in Blue Catfish growth over space and time (Table 1). We fitted Model 0 (assuming similar growth over space and time) using nonlinear least squares regression. We fitted nonlinear mixed effects models corresponding to alternative hypotheses using the nlmer function in the lme4 package (Bates et al. 2015) in R version 3.1.3 (R Core Team 2015). Six candidate models were examined with random effects of river, collection year, and cohort on $L_{\infty}$ and $k$ (Table 1). The $t_{0}$ parameter was not allowed to vary via random effects as we assumed differences in size early in life among populations and over time were likely negligible. The VBGF fitted to all length-at-age observations undifferentiated with respect to time and space (Model 0) was compared to nonlinear mixed effects models. Model adequacy was assessed using the Akaike Information Criterion with the small-sample-size correction (AICc), providing a criterion to rank models (Hurvich and Tsai 1989; Burnham and Anderson 2002). Models were compared based on AICc, where models with lower AICc values were considered superior to those with larger AICc values (Guthery 2008).

Uncertainty surrounding von Bertalanffy parameters of nonlinear mixed effects models was assessed using nonparametric bootstrapping (Thai et al. 2014). We sampled the original dataset with replacement 500 times and fit nonlinear mixed effect models to the resampled datasets. The 500 estimates for each parameter were summarized to estimate standard deviation, 95\% confidence intervals (percentile method; Carpenter and Bithell 2000), and the coefficient of variation for parameter estimates. Bootstrap sample sizes within random effects groupings were based on sample sizes of the original data to ensure estimated of uncertainty were not influenced by differences in the numbers of samples within groupings across bootstrap iterations.

As we used an information theoretic approach to determine which model best explained variability in length-at-age, we wanted to statistically determine if trends existed over the study period. We tested for trends in mean length-at-age over time using simple linear regression for 
211 the ages $1,4,7,10$, and 13. This analysis allowed us to examine differences in length at like ages

212 for cohorts over time. We also examined the spatial synchrony of growth responses by

213 examining residuals from the linear trend test models discussed above. Using the residuals

214 allowed us to examine growth among rivers with the overall trends removed. Spatial synchrony

215 was assessed using the Pearson rank correlation test via pairwise river comparisons of residuals

216 from the regression of mean length-at-age and collection years. We were unable to examine

217 synchrony of age-1 growth in the James and Rappahannock rivers due to differences in sampling

218 schedules and a lack of age-1 fish in some years. Significance was assessed at $\alpha=0.05$.

219

220

221

222

223

224

225

226

227

228

229

230

231

232

233

234

235

236

237

238

239

240

We examined growth differences between native and non-native Blue Catfish populations to understand if non-native populations grow faster and how non-native Virginia populations compare over time. We included studies based on otolith ages (as spines may underestimate ages, Nash and Irwin 1999; Buckmeier et al. 2002; Olive et al. 2011) that presented fitted von Bertalanffy growth models or mean length-at-age data from which a von Bertalanffy growth model could be fitted. Excluding spine-based studies and those with different data types, we examined 12 native populations and 3 non-native populations (Table 3), in addition to the 4 nonnative Virginia populations examined in the present study. Non-native populations from Altamaha River, Georgia, USA and Lake Norman, North Carolina, USA were sampled 5 and 42-44 years after Blue Catfish was first reported, respectively. Records for Blue Catfish introductions in Badin Lake, North Carolina, USA were unavailable (Dorsey et al. 2011). We plotted the fitted models to see how interpretation of native and non-native growth comparisons may differ over time for Virginia Blue Catfish.

$<$ A $>$ Results

A total of 9,650 Blue Catfish was sampled for age analysis from the James, Mattaponi, Pamunkey, and Rappahannock rivers from 2002 to 2016. We analyzed the growth of 9,650 fish from these four river systems over the 15-year period. Observed $L_{T}$ ranged from 20 to $1330 \mathrm{~mm}$. The maximum observed age in the whole dataset was 25 years, but varied by river and year. Maximum observed age within rivers increased over the sampling period in the James (simple linear regression, $F=113.6, \mathrm{df}=1,5, P<0.001)$, Mattaponi $(F=245.2, \mathrm{df}=1,6, P<0.001)$, and Pamunkey $(F=337.2, \mathrm{df}=1,7, P<0.001)$ rivers, but not the Rappahannock River $(F=0.7656$, $\mathrm{df}=1,6, P=0.4152)$. Length-at-age was variable, differing by as much as $700 \mathrm{~mm}$ for individual 
ages among the rivers examined. Sample sizes from respective rivers and sampling years are provided in Table 2 .

The best model describing established Blue Catfish growth patterns in Virginia's tidal rivers featured river and cohort as random effects on the parameters $L_{\infty}$ and $k$ (Model River:Cohort), supporting hypothesis $\mathrm{H}_{5}$. Hypothesis $\mathrm{H}_{4}$ had the second most support, but the corresponding model (Model River:Year) had a large $\triangle \mathrm{AICc}$ when compared to the best model $(\triangle \mathrm{AICc}=824.7)$. Models considering spatial and temporal differences in growth simultaneously were superior to models considering spatial or temporal differences only (Table 4). The VBGF without random effects (Model 0, hypothesis $\mathrm{H}_{0}$ ) was inferior to all other models based on AICc (more than 5,000 AICc units from the best model). Correlations in parameters from fitted models indicated a negative correlation in $L_{\infty}$ and $k$.

We observed a decline in mean length-at-age through time, and greater variability for older age classes (Figure 2). Similarly, predicted length-at-age from Model River:Year decreased over time, and fit data well (Figure 3). Predicted length-at-age seemed to be similar at early ages and diverged at older ages. However, seemingly random variability among cohorts was evident when mean length-at-age is compared within ages within rivers (Figure 2). A decrease in $L_{\infty}$ existed in the James River when examining cohorts, although temporal fluctuations were evident. Other river systems exhibited modest declines. Estimates of $k$ for Model River:Cohort tracked $L_{\infty}$ as the two were generally negatively correlated. Older cohorts grew faster than more recent cohorts leading to growth patterns with unreasonable estimates of $L_{\infty}$. Further, truncated age structures for more recently established populations (e.g., Pamunkey in 2003) or low sample sizes (e.g., Rappahannock in 2004) could also contribute to large $L_{\infty}$ estimates. An increase in $L_{\infty}$ toward the end of the time series for Model River:Cohort was likely an artifact of sampling fish not yet old enough to exhibit ontogenetic declines in individual growth rate, whereas increases early in the time series likely indicate greater availability of larger fish in subsequent years as populations matured.

The trend analysis using simple linear regression revealed significant negative trends in length-at-age for most ages and rivers from 2002-2016 (Table 5). Mean length-at-age declined significantly for all ages examined $(1,4,7,10$, and 13) in the James, Mattaponi, and Pamunkey rivers. However, we did not detect significant declines for ages 1 and 4 in the Rappahannock 
271 River. We made 28 pairwise comparisons to assess synchrony among rivers. Due to differences

272 in sampling schedules, correlations were based on 4 to 7 years of data points depending on the

273 rivers compared. Synchrony was only detected in a few cases (James/Rappahannock-age 4,

274 Mattaponi/Rappahannock-age 4, Pamunkey/Rappahannock-age 7, Mattaponi/Pamunkey-age 10,

275 Pamunkey/Rappahannock-age 10).

276

277

278

279

280

281

282

283

284

285

286

287

288

289

290

291

292

293

294

295

296

297

298

299

300

Visual examination of native and non-native Blue Catfish fitted von Bertalanffy models indicated substantial variability existed among native populations (Figure 4). Non-native populations exhibited growth trajectories in the middle of the native population range or greater. The Rappahannock River in 2016 exhibited the slowest growth among non-native populations examined. Non-native populations from the Altamaha River and Badin Lake grew faster than most native populations and generally faster than Virginia non-native populations. Lake Norman, however, appears to have unremarkably fast or slow growth compared to other populations.

$<\mathrm{A}>$ Discussion

Growth of Blue Catfish differed among cohorts and rivers with some significant declines in length-at-age during the establishment and expansion phases of the invasion. Consequently, comparing growth of invasive species within their native and non-native range appears to be more complicated than often presented. Frequently, scientists are interested in whether nonnative populations grow more quickly than those in the native range. In some cases, non-native species grow faster than native species (Kwak et al. 2006, Sakaris et al. 2006) and other cases native populations grow faster (Copp et al. 2004; Copp et al. 2016) or there is no difference (Rypel 2014). Changes in growth over time may make comparisons only applicable during the time period in which data were collected and contribute to the mixed results observed. In the present study, growth transitioned from being faster than many native populations to a state where it was average or below average compared to native populations. Kwak et al. (2006) reported slower growth from more recent cohorts of Flathead Catfish Pylodictis olivaris and suggested declines in growth may be related to resource depletion during establishment. Conversely, Kaeser et al. (2011) observed differences in growth over time with faster growth later in their study period. Massie et al. (2018) reported no influence of time since introduction on Flathead Catfish growth, but suspected their study lacked populations that were introduced recently enough to observe a difference. Considering the time since introduction of populations 
may be important when comparing growth of invasive species to avoid making conclusions that may not apply over time. However, this topic requires further study to understand interactions of growth dynamics, environmental factors, and native status.

We found a reduction in length-at-age as populations matured in the James, Mattaponi and Pamunkey rivers. Our results are consistent with other studies examining non-native species, where growth and body sizes were reduced in older populations (Young et al. 2010; Gutowsky and Fox 2011; Feiner et al. 2012; Brandner et al. 2018). Density dependent factors are known to reduce growth rates of fishes (Ryman and Myers 1992; Bohlin et al 2002) and may contribute to the observed declines in the present study. Two studies in Virginia tidal rivers reported Blue Catfish growth was negatively correlated with indices of relative abundance (Greenlee and Lim 2011; Nepal and Fabrizio 2020). Mean length-at-age appears to level off for ages 4, 7, and 10 around the time estimated biomass stabilized in an unpublished study by Orth et al. (2017). However, a study on Channel Catfish Ictalurus punctatus reported growth was density independent when controlling for environmental factors in Mississippi, USA floodplain rivers (Shephard and Jackson 2009). Fishing can also influence growth as populations optimize life history traits in response to elevated mortality rates (van Walraven 2010; Enberg et al. 2012). Reported commercial catfish harvest in Virginia has doubled since 1993 to over 1000 tonnes in 2016 (Orth et al. 2017). However, opportunities to evaluate the role of exploitation are limited as available harvest data lack size information, estimates of recreational harvest, and species reporting prior to 2010. Further, as sampling was conducted in habitats preferred by large individuals, study-induced mortality from otolith collection may also present a selective pressure. It seems plausible that density dependence, as well as fishing and study-induced mortality has contributed to the observed changes in growth, but currently available data lack utility to evaluate their influences. As we generally were unable to detect synchrony in growth dynamics among rivers, system-specific factors may be more influential than region-scale environmental processes. Spatial growth dynamics may be related to differences in population demographics due to differences in introduction history.

We detected declines in growth over time, as well as differences among rivers. The Rappahannock River was the only system to have age classes where significant declines in growth rates were not detected. Examination of biomass estimates supported that biomass 
stabilized earliest in the Rappahannock among the James, Rappahannock, and York rivers (Orth et al. 2017). The Rappahannock generally had the slowest growth among the four rivers examined. For many of the temporal comparisons of younger age classes, mean length-at-age in the James, Mattaponi, and Pamunkey rivers stabilized following the mid-2000s, when it is believed abundances peaked in the James River (Bunch et al. 2018). Differences among rivers may also be related to river productivity, however, the Rappahannock River is more productive than the York River (Nesius et al. 2007). The Chesapeake Bay and many of its tributaries are highly productive due to human land use practices leading to eutrophication (Kemp et al. 2005) and likely contributed to Blue Catfish's successful establishment (Bauer 2012). However, more productive rivers (Rappahannock and James, Nesius et al. 2007) were stocked first and have the highest abundances (Orth et al. 2017), making disentangling biotic and abiotic influences on Blue Catfish growth difficult.

We observed wide variability in individual growth among and within cohorts. For instance, length ranged more than $500 \mathrm{~mm}$ for age-12 Blue Catfish from the 1998 cohort in the James River. Other studies have also observed wide variability in Blue Catfish growth among and within populations (Mauck and Boxrucker 2004; Boxrucker and Kuklinski 2006). Wide variability in length-at-age prompted Greenlee and Lim (2011) to declare that age-length keys were not valuable for these populations. Variability in growth could stem from several factors including sex, dietary variability or habitat. In terms of sex, male Blue Catfish have been reported to grow larger than females (Marshall et al. 2009). Diets of Blue Catfish are highly variable, as the species appears to function as an opportunistic omnivore in these subestuaries (Schmitt et al. 2017, 2019b). Further, tidal rivers are dynamic systems at the interface of freshwater and marine environments (Hoitnik and Jay 2016) and habitats with flowing currents and optimal temperatures may promote greater growth rates (Rypel 2011). In addition, stress from increased salinity during summertime may reduce growth in fish occupying downstream reaches of these rivers. Electrofishing's reduced effectiveness in high conductivity water limited the present study to less saline portions of these subestuaries (Warry et al. 2013; Schmitt et al. 2019a), so we could not assess growth differences within rivers. Understanding growth patterns over this gradient of environmental conditions could improve our understanding of factors influencing Blue Catfish growth. However, Blue Catfish are highly mobile with variable movement patterns among individuals (Timmons 1999; Garrett and Rabeni 2011; Tripp et al. 
2011; Tuckey et al. 2017) and inferences based on collection site conditions may be confounded by conditions at other utilized habitats. Future work should consider tag-recapture studies to explore drivers and consequences of individual variation in growth (Punt et al. 2016).

This study adds to the literature base on invader life history over time by considering growth differences over space and time for populations with different introduction histories. The time series and spatial extent of this study exceeds those of many other studies on non-native life history changes. We recommend consideration of introduction history when comparing native and non-native life history traits, as life history characteristics for non-native populations appear to vary temporally. We recommend evaluations of invasive species control measures include sensitivity analyses, as life history may change during establishment or in response to control strategies (Bonvechio et al. 2011a). Further, future work would benefit from estimates of abundance, as well as collection of more detailed information on harvest (commercial, recreational, or removal efforts) and environmental variables to improve our understanding of invasion ecology and shifts in life history during an invasion.

$<\mathrm{A}>$ Acknowledgements

We thank Virginia Department of Game and Inland Fisheries for funding this project and their efforts to collect and organize data. We thank Virginia Sea Grant for student support of C.D. Hilling through a Graduate Research Fellowship. We also thank P. L. Angermeier, M. C. Fabrizio, P. H. Michaletz, T. J. Kwak, the associate editor, and two anonymous reviewers for their thoughtful comments that vastly improved the quality of this manuscript. Any use of trade, firm, or product names is for descriptive purposes only and does not imply endorsement by the U.S. Government.

$<\mathrm{A}>$ References

Aguilar, R., M. B. Ogburn, A. C. Driskell, L. A. Weigt, M. C. Groves, and A. H. Hines. 2017. Gutsy genetics: identification of digested piscine prey items in the stomach contents of sympatric native and introduced warmwater catfishes via DNA barcoding. Environmental Biology of Fishes 100:325-336. 
Azour, F., M. van Deurs, J. Behrens, H. Carl, K. Hüssy, K. Greisen, R. Ebert, and P. R. Møller. 2015. Invasion rate and population characteristics of the Round Goby Neogobius melanostomus: effects of density and invasion history. Aquatic Biology 24:41-52.

Bates, D., M. Maechler, B. Bolker, S. Walker, R. H. B. Chistensen, H. Singmann, B. Dai, and G. Grothendieck. 2015. 1me4: Linear mixed-effects models using 'Eigen' and S4. R package version 1.1-10.

Bauer, J. T. 2012. Invasive species: "back-seat drivers" of ecosystem change? Biological Invasions 14:1295-1304.

Bodine, K. A., and D. E. Shoup. 2010. Capture efficiency of Blue Catfish electrofishing and the effects of temperature, habitat, and reservoir location on electrofishing-derived length structure indices and relative abundance. North American Journal of Fisheries Management 30:613-621.

Bohlin, T., L. F. Sundström, J. I. Johnsson, J. Höjesjö, and J. Pettersson. 2002. Densitydependent growth in Brown Trout: effects of introducing wild and hatchery fish. Journal of Animal Ecology 71:683-692.

Bøhn, T., O. T. Sandlund, P. Amundsen, and R. Primicerio. 2004. Rapidly changing life history during invasion. Oikos 106:138-150.

Bonvechio, T. F., M. S. Allen, D. Gwinn, and J. S. Mitchell. 2011a. Impacts of electrofishing removals on the introduced Flathead Catfish population in the Satilla River, Georgia. Pages 395-407 in P. H. Michaletz and V. H. Travnichek, editors. Conservation, ecology and management of catfish: the second international symposium. Symposium 77, American Fisheries Society, Bethesda, Maryland.

Bonvechio, T. F., C. A. Jennings, and D. R. Harrison. 2011b. Diet and population metrics of the introduced Blue Catfish on the Altamaha River, Georgia. Proceedings of the Annual Conference of the Southeastern Association of Fish and Wildlife Agencies 65:112-118.

Brandner, J., A. F. Cerwenka, U. K. Schliewen, and J. Geist. 2013. Bigger is better: characteristics of Round Goby forming an invasion front in the Danube River. PLoS ONE 8: e73036. 
Brandner, J., A. F. Cerwenka, U. K. Schliewen, and J. Geist. 2018. Invasion strategies in Round Goby (Neogobius melanostomus): is bigger really better? PLoS ONE 13:e0190777.

Boxrucker, J., and K. Kuklinski. 2006. Abundance, growth, and mortality of selected Oklahoma Blue Catfish populations: implications for management of trophy fisheries. Proceedings of the Annual Conference of the Southeastern Association of Fish and Wildlife Agencies $60: 152-156$.

Buckmeier, D. L., E. R. Irwin, R. K. Betsill, and J. A. Prentice. 2002. Validity of otoliths and pectoral spines for estimating ages of Channel Catfish. North American Journal of Fisheries Management 22:934-942.

Bunch, A. J., R. S. Greenlee, and E. M. Brittle. 2018. Blue Catfish density and biomass in a tidal tributary in coastal Virginia. Northeastern Naturalist 25:333-340.

Burnham, K. P., and D. R. Anderson. 2002. Model selection and multimodel inference: A practical information-theoretic approach. Springer-Verlag, New York.

Carpenter, J., and J. Bithell. 2000. Bootstrap confidence intervals: when, which, what? A practical guide for medical statisticians. Statistics in Medicine 19:1141-1164.

Copp, G. H., M. G. Fox, M. Przybylski, F. N. Godinho, and A. Vila-Gispert. 2004. Life-time growth patterns of Pumpkinseed Lepomis gibbosus introduced to Europe, relative to native North American populations. Folia Zoologica-Praha 53:237-254.

Copp, G. H., A. S. Tarkan, G. Masson, M. J. Godard, J. Koščo, V. Kováč, A. Novomeská, R. Miranda, J. Cucherousset, G. Pedicillo, and B. G. Blackwell. 2016. A review of growth and life-history traits of native and non-native European populations of Black Bullhead Ameiurus melas. Reviews in Fish and Fish Biology 26:441-469.

Dorsey, L. G., B. J. McRae, and T. M. Thompson. 2011. Evaluation of an 813-mm maximum size limit for Blue Cafish in two North Carolina reservoirs. Pages 177-185 in P. H. Michaletz and V. H. Travnichek, editors. Conservation, ecology and management of catfish: the second international symposium. Symposium 77, American Fisheries Society, Bethesda, Maryland. 
Enberg, K., C. Jørgensesn, E. S. Dunlop, Ø. Varpe, D. S. Boukal, L. Baulier, S. Eliassen, and M. Heino. 2012. Fishing-induced evolution of growth: concepts, mechanisms and the empirical evidence. Marine Ecology 33:1-25.

Fabrizio, M. C., T. D. Tuckey, R. J. Latour, G. C. White, and A. J. Norris. 2018. Tidal habitats support large numbers of invasive Blue Catfish in a Chesapeake Bay subestuary. Estuaries and Coasts 41:827-840.

Feiner, Z. S., D. D. Aday, and J. A. Rice. 2012. Phenotypic shifts in White Perch life history strategy across stages of invasion. Biological Invasions 14:2315-2329.

Fuller, P., and M. Neilson. 2019. Ictalurus furcatus (Valenciennes in Cuvier and Valenciennes, 1840): U.S. Geological Survey, Nonindigenous Aquatic Species Database, Gainesville, FL, https://nas.er.usgs.gov/queries/FactSheet.aspx?speciesID=740, Revision Date: 11/16/2018, Peer Review Date: 4/1/2016, Accessed: 8 March 2019

Garrett, D. L., and C. F. Rabeni. 2011. Intra-annual movement and migration of Flathead Catfish and Blue Catfish in the lower Missouri River and tributaries. Pages 495-509 in P. H. Michaletz and V. H. Travnichek, editors. Conservation, ecology and management of catfish: the second international symposium. Symposium 77, American Fisheries Society, Bethesda, Maryland.

Graham, K. 1999. A review of the biology and management of Blue Catfish. Pages 37-49 in E. R. Irwin, W. A. Hubert, C. F. Rabeni, H. L. Schramm Jr., and T. Coon, editors. Catfish 2000: proceedings of the international ictalurid symposium. Symposium 24, American Fisheries Society, Bethesda, Maryland.

Grant, J. W. A., and I. Imre. 2005. Patterns of density-dependent growth in juvenile streamdwelling salmonids. Journal of Fish Biology 67: 100-110.

Greenlee, R. S., and C. N. Lim. 2011. Searching for equilibrium: population parameters and variable recruitment in introduced Blue Catfish populations in four Virginia tidal river systems. Pages 349-367 in P. H. Michaletz and V. H. Travnichek, editors. Conservation, ecology and management of catfish: the second international symposium. Symposium 77, American Fisheries Society, Bethesda, Maryland. 
472 Guthery, F. S. 2008. Primer on natural resource science. Texas A\&M University Press, College 473 Station, Texas.

474 475

476

Gutowsky, L. F. G., and M. G. Fox. 2011. Occupation, body size and sex ratio of Round Goby (Neogobius melanostomus) in established and newly invaded areas of an Ontario river. Hydrobiologia 671:27-37.

Haddon, M. 2011. Modelling and quantitative methods in fisheries, $2^{\text {nd }}$ Edition. Chapman and Hall/CRC, Boca Raton, Florida.

Hilling, C. D., A. J. Bunch, R. S. Greenlee, D. J. Orth, and Y Jiao. 2018. Natural mortality and size structure of introduced Blue Catfish in Virginia tidal rivers. Journal of the Southeastern Association of Fish and Wildlife Agencies 5:30-38.

Holley, M. P., M. D. Marshall, and M. J. Maceina. 2009. Fishery and population characteristics of blue catfish and channel catfish and potential impacts of minimum length limits on the fishery in Lake Wilson, Alabama. North American Journal of Fisheries Management 29:1183-1194.

Hoitnik, A. J. F., and D. A. Jay. 2016. Tidal river dynamics: implications for deltas. Reviews of Geophysics 54:240-272.

Homer Jr., M. D., and C. A. Jennings. 2011. Historical catch, age structure, sizes, and relative growth for an introduced population of Blue Catfish in Lake Oconee, Georgia. Pages 383-394 in P. H. Michaletz and V. H. Travnichek, editors. Conservation, ecology and management of catfish: the second international symposium. Symposium 77, American Fisheries Society, Bethesda, Maryland.

Houde, E. 2006. A fisheries ecosystem plan for the Chesapeake Bay. Pages 1-12 in Chesapeake Bay Fisheries Ecosystem Advisory Panel (National Oceanic and Atmospheric Administration Chesapeake Bay Office). Fisheries ecosystem planning for Chesapeake Bay. American Fisheries Society, Trends in Fisheries Management 3, Bethesda, Maryland.

Jenkins, R. E., and N. M. Burkhead. 1994. Freshwater fishes of Virginia. American Fisheries Society, Bethesda, Maryland. 
Jenkins Jr., T. M., S. Diehl, K. W. Kratz, and S. D. Cooper. 1999. Effects of population density on individual growth of Brown Trout in streams. Ecology 80:941-956.

Jennings, C. A., G. E. Mitchell, and C. Nelson. 2018. Seasonal food habits of introduced Blue Catfish in Lake Oconee, Georgia. Journal of the Southeastern Association of Fish and Wildlife Agencies 5:39-45.

Jensen, A. L. 1996. Beverton and Holt life history invariants result from optimal trade-off of reproduction and survival. Canadian Journal of Fisheries and Aquatic Sciences 53:820822.

Jiao, Y. Rogers-Bennett, L., Taniguchi, I., Butler. J., and Crone, P. 2010. Incorporating temporal variation in the growth of red abalone (Haliotis rufescens) using hierarchical Bayesian growth model. Canadian Journal of Fisheries and Aquatic Sciences 67:730-742.

Jones, G. P. 1986. Food availability affects growth in a coral reef fish. Oecologia 70: 136-139.

Kaeser, A. J., T. F. Bonvechio, D. Harrison, and R. R. Weller. 2011. Population dynamics of introduced Flathead Catfish in river of southern Georgia. Pages 409-422 in P. H. Michaletz and V. H. Travnichek, editors. Conservation, ecology and management of catfish: the second international symposium. Symposium 77, American Fisheries Society, Bethesda, Maryland.

Kemp, W. M., W. R. Boynton, J. E. Adolf et al. 2005. Eutrophication of Chesapeake Bay: historical trends and ecological interactions. Marine Ecology Progress Series 303:1-29.

Kerns, J. A., and L.A. Lombardi-Carlson. 2017. History and importance of age and growth information. Pages 1-8 in M. C. Quist and D. A. Isermann, editors. Age and growth of fishes: principles and techniques. American Fisheries Society, Bethesda, Maryland.

Kitchell, J. F., D. J. Stewart, and D. Weininger. 1977. Applications of a bioenergetics model to Yellow Perch (Perca flavescens) and Walleye (Stizostedion vitreum vitreum). Journal of the Fisheries Board of Canada 34:1922-1935.

Kornis, M. S., B. C. Weidel, and M. J. Vander Zanden. 2017. Divergent life histories of invasive Round Gobies (Neogobius melanostomus) in Lake Michigan and its tributaries. Ecology of Freshwater Fish 26:563-574. 
528

529

530

531

532

533

534

535

536

537

538

539

540

541

542

543

544

545

546

547

548

549

550

551

552

553

554

555

Kwak, T. J., D. S. Waters, and W. E. Pine III. 2006. Age, growth and mortality of introduced Flathead Catfish in Atlantic rivers and a review of other populations. North American Journal of Fisheries Management 26:73-87.

Liebl, A. L., A. W. Schrey, C. L. Richards, and L. B. Martin. 2013. Patterns of DNA methylation throughout a range expansion of an introduced songbird. Integrative and Comparative Biology 53:351-358.

Long, J. M., and D. R. Stewart. 2010. Verification of otolith identity used by fisheries scientists for aging Channel Catfish. Transactions of the American Fisheries Society 139:17751779.

Ma, Q., Y. Jiao, and Y. Ren. 2017. Linear mixed-effects models to describe length-weight relationships for Yellow Croaker (Larimichthys polyactis) along the north coast of China. PLoS ONE 12, e0171811.

Marshall, M. D., M. J. Maceina, and M. P. Holley. 2009. Age and growth variability between sexes of three catfish species in Lake Wilson, Alabama. North American Journal of Fisheries Management 5:1283-1286.

Massie, D. L., G. D. Smith, T. F. Bonvechio, A. J. Bunch, D. O. Lucchesi, and T. Wagner. 2018. Spatial variability and macro-scale driver of growth for native and introduced Flathead Catfish populations. Transactions of the American Fisheries Society 147:554-565.

Masson, L., J. W. Brownscombe, and M. G. Fox. 2016. Fine scale spatio-temporal life history shifts in an invasive species at its expansion front. Biological Invasions 18:775-792.

Mauck, P. and J. Boxrucker. 2004. Abundance, growth, and mortality of the Lake Texoma Blue Catfish population: implications for management. Proceedings of the Annual Conference of the Southeastern Association of Fish and Wildlife Agencies 58:57-65.

Moran, Z., D. J. Orth, J. D. Schmitt, E. M. Hallerman, and R. Aguilar. 2016. Effectiveness of DNA barcoding for identifying piscine prey items in stomach contents of piscivorous catfishes. Environmental Biology of Fishes 99:161-167.

Nash, M. K. and E. R. Irwin. 1999. Use of otoliths versus pectoral spines for ageing adult Flathead Catfish. Pages 309-316 in E. R. Irwin, W. A. Hubert, C. F. Rabeni, H. L. 
Schramm Jr., and T. Coon, editors. Catfish 2000: proceedings of the international ictalurid symposium. Symposium 24, American Fisheries Society, Bethesda, Maryland.

Nepal, V., and M. C. Fabrizio. 2019. High salinity tolerance of invasive Blue Catfish suggests potential for further range expansion in the Chesapeake Bay region. PLoS ONE 14(11):e0224770. https://doi.org/10.1371/journal.pone.0224770

Nepal, V., and M. C. Fabrizio. 2020. Density-dependence mediates the effects of temperature on growth of juvenile Blue Catfish in nonnative habitats. Transactions of the American Fisheries Society 149:108-120.

Nesius, K. K., H. G. Marshall, and T. A. Egerton. 2007. Phytoplankton productivity in the tidal regions of four Chesapeake Bay (U.S.A) tributaries. Virginia Journal of Science 58:191204.

Olive, J., H. L. Schramm Jr., P. D. Gerard, and E. Irwin. 2011. An evolution of agreement between pectoral spines and otoliths for estimating ages of catfishes. Pages 679-688 in P. H. Michaletz and V. H. Travnichek, editors. Conservation, ecology and management of catfish: the second international symposium. Symposium 77, American Fisheries Society, Bethesda, Maryland.

Orth, D. J., Y. Jiao, J. D. Schmitt, C. D. Hilling, J. A. Emmel, and M. C. Fabrizio. 2017. Dynamics and role of non-native Blue Catfish Ictalurus furcatus in Virignia's tidal rivers. Virginia Department of Game and Inland Fisheries, Project 2012-13705, Technical Report, Henrico.

Phillips, B. L., G. P. Brown, R. Shine. 2010. Life-history evolution in range-shifting populaions. Ecology 91:1617-1627.

Prentis, P. J., J. R. U. Wilson, E. E. Dormontt, D. M. Richardson, and A. J. Lowe. 2008. Adaptive evolution in invasive species. Trends in Plant Science 13:288-294.

Punt, A. E., M. Haddon, and R. McGarvey. 2016. Estimating growth within size-structured fishery stock assessments: what is the state of the art and what does the future look like? Fisheries Research 180:147-160. 
Quinn Jr., T. J., and R. B. Deriso. 1999. Quantitative fish dynamics. Oxford University Press, New York.

R Core Team. 2015. R: A language and environment for statistical computing. R Foundation for Statistical Computing, Vienna, Austria.

Richards, C. L., A. W. Schrey, and M. Pigliucci. 2012. Invasion of diverse habitats by few Japanese knotweed genotypes is correlated with epigenetic differentiation. Ecology Letters 15:1016-1025.

Rieman, B. E., and D. L. Myers. 1992. Influence of fish density and relative productivity on growth of Kokanee in ten oligotrophic lakes and reservoirs in Idaho. Transactions of the American Fisheries Society 121:178-191.

Rypel, A. L. 2011. Meta-analysis of growth for five North American catfishes: effects of climate, hydrologic habitat, and latitudinal countergradients. Pages 661-677 in P. H. Michaletz and V. H. Travnichek, editors. Conservation, ecology and management of catfish: the second international symposium. Symposium 77, American Fisheries Society, Bethesda, Maryland.

Rypel, A. L. 2014. Do invasive freshwater fish species grow better when they are invasive? Oikos 123:279-289.

Sakaris, P. C., E. R. Irwin, and D. Harrison. 2006. Comparison of native and introduced Flathead Catfish populations in Alabama and Georgia: growth, mortality, and management. North American Journal of Fisheries Management 26:867-874.

Schloesser, R. W., M. C. Fabrizio, R. J. Latour, G. C. Garman, R. S. Greenlee, M. Groves, and J. Gartland. 2011. Ecological role of Blue Catfish in Chesapeake Bay communities and implications for management. Pages 369-382 in P. H. Michaletz and V. H. Travnichek, editors. Conservation, ecology and management of catfish: the second international symposium. Symposium 77, American Fisheries Society, Bethesda, Maryland.

Schmitt, J. D., E. M. Hallerman, A. Bunch, Z. Moran, J. A. Emmel, and D. J. Orth. 2017. Predation and prey selectivity by nonnative catfish on migrating alosines in an Atlantic 
slope estuary. Marine and Coastal Fisheries: Dynamics, Management, and Ecosystem Science 9:108-125.

Schmitt, J. D., B. K. Peoples, A. J. Bunch, L. Castello, and D. J. Orth. 2019a. Modeling the predation dynamics of invasive Blue Catfish (Ictalurus furcatus) in the Chesapeake Bay. Fishery Bulletin 117(4): 277-290.

Schmitt, J. D., B. K. Peoples, L. Castello, and D. J. Orth. 2019b. Feeding ecology of a generalist consumer: A case study of invasive Blue Catfish Ictalurus furcatus in the Chesapeake Bay. Environmental Biology of Fishes 102:443-465.

Schulte, D. M. 2017. History of the Virginia oyster fishery in Chesapeake Bay, USA. Frontiers of Marine Science 4:127. doi: 10.3389/fmars.2017.00127

Shephard, S., and D. C. Jackson. 2009. Density-independent growth of floodplain river Channel Catfish Ictalurus punctatus. Journal of Fish Biology 74:2409-2414.

Stewart, D. R., G. W. Benz, and G. D. Scholten. 2009. Weight-length relationships and growth data for Blue Catfish from four Tennessee waterbodies. Proceedings of the Annual Conference of the Southeastern Association of Fish and Wildlife Agencies 63:140-146.

Tango, P. J., and R. A. Batiuk. 2016. Chesapeake Bay recovery and factors affecting trends: long-term monitoring, indicators, and insights. Regional Studies in Marine Science 4:1220.

Tarkan, A. S., Ö. Gaygusuz, Ç. Gürsoy Gaygusuz, and G. Copp. 2012. Circumstantial evidence for Gibel Carp Carassius gibelio reproductive competition exerted on native fish species in a mesotrophic reservoir. Fisheries Management and Ecology 19:167-177.

Thai, H., F. Mentré, G. Holford, C. Veyrat-Follet, and E. Comets. 2014. Evaluation of bootstrap methods for estimating uncertainty of parameters in nonlinear mixed-effects models: a simulation study in population pharmacokinetics. Journal of Pharmacokinetics and Pharmacodynamics 41:15-33.

Timmons, T. J. 1999. Movement and exploitation of Blue and Channel Catfish in Kentucky Lake. Pages 187-191 in E. R. Irwin, W. A. Hubert, C. F. Rabeni, H. L. Schramm Jr., and 
637

638

639

640

641

642

643

644

645

646

647

648

649

650

651

652

653

654

655

656

657

658

659

660

661

662

663

664

T. Coon, editors. Catfish 2000: proceedings of the international ictalurid symposium. Symposium 24, American Fisheries Society, Bethesda, Maryland.

Tripp, S. J., M. J. Hill, H. A. Calkins, R. C. Brooks, D. P. Herzog, D. E. Ostendorf, R. A. Hrabik, R. A., and J. E. Garvey. 2011. Blue Catfish movement in the upper Mississippi River. Pages 511-519 in P. H. Michaletz and V. H. Travnichek, editors. Conservation, ecology and management of catfish: the second international symposium. Symposium 77, American Fisheries Society, Bethesda, Maryland.

Tuckey, T. D., M. C. Fabrizio, and A. J. Norris. 2017. Low apparent survival and heterogenous movement patterns of invasive Blue Catfish in a coastal river. Marine and Coastal Fisheries: Dynamics, Management, and Ecosystem Science 9:564-572.

van Walraven, L., F. M. Mollet, C. J. G. van Damme, and A. D. Rijnsdorp. 2010. Fisheriesinduced evolution in growth, maturation and reproductive investment of the sexually dimorphic North Sea Plaice (Pleuronectes platessa L.). Journal of Sea Research 64:8593.

Vincenzi, S., M. Mangel, A. J. Crivelli, S. Munch, and H. J. Skaug. 2014. Determining individual variation in growth and its implications for life-history and population processes using the empirical Bayes method. PloS Computational Biology 10, e1003828.

Vokoun, J. C., and C. F. Rabeni. 1999. Catfish sampling in rivers and streams: a review of strategies, gears, and methods. Pages 271-286 in E. R. Irwin, W. A. Hubert, C. F. Rabeni, H. L. Schramm Jr., and T. Coon, editors. Catfish 2000: proceedings of the international ictalurid symposium. Symposium 24, American Fisheries Society, Bethesda, Maryland.

Warry, F. Y., P. Reich, J. S. Hindell, J. McKenzie, and A. Pickworth. 2013. Using new electrofishing technology to amp-up fish sampling in estuarine habitats. Journal of Fish Biology 82:1119-1137. 
666

667

668

669

670

671

\begin{tabular}{clll}
\hline Hypothesis & \multicolumn{1}{c}{ Explanation } & Model & Model description \\
\hline $\mathrm{H}_{0}$ & Similar growth over space/time & Model 0 & No RE \\
$\mathrm{H}_{1}$ & Growth varies by river & Model River & River as RE of $L_{\infty} \& k$ \\
$\mathrm{H}_{2}$ & Growth varies by year & Model Year & Year as RE of $L_{\infty} \& k$ \\
$\mathrm{H}_{3}$ & Growth varies by cohort & Model Cohort & Cohort as RE of $L_{\infty} \& k$ \\
$\mathrm{H}_{4}$ & Growth varies by river \& year & Model River:Year & Year \& river as RE of $L_{\infty} \& k$ \\
$\mathrm{H}_{5}$ & Growth varies by river \& cohort & Model River:Cohort & Cohort \& river as RE of $L_{\infty} \& k$ \\
\hline
\end{tabular}

672

673 TABLE 2. Rivers and years sampled for Blue Catfish Ictalurus furcatus otoliths from four

674 Virginia tidal rivers from 2002 to 2016. Numbers indicate sample sizes, whereas the number of

675 sampling sites are given in parentheses. Blue Catfish were collected exclusively using low-

676 frequency electrofishing, except where an * indicates low-frequency samples were supplemented

677 with high-frequency electrofishing.

678

\begin{tabular}{ccccc}
\hline Year & James & Mattaponi & Pamunkey & Rappahannock \\
\hline 2002 & $330(11)$ & $178(6)$ & $150(7)$ & $245^{*}(6)$ \\
2003 & 0 & $175(9)$ & $362(10)$ & 0 \\
2004 & $216(5)$ & $130(4)$ & $187(4)$ & $126^{*}(2)$ \\
2005 & 0 & 0 & $300(7)$ & $410^{*}(6)$ \\
2006 & $536(11)$ & $304(7)$ & $333(9)$ & 0 \\
2007 & 0 & 0 & 0 & $230^{*}(6)$ \\
2008 & $470(10)$ & $266(7)$ & $287(9)$ & 0 \\
2009 & 0 & 0 & 0 & $383^{*}(7)$ \\
2010 & $445(11)$ & 0 & $357(10)$ & 0 \\
2011 & 0 & $254(7)$ & 0 & $355(9)$ \\
2014 & $372(9)$ & $207(7)$ & $422(10)$ & $307(10)$ \\
2016 & $458(13)$ & $266(7)$ & $284(8)$ & $305(9)$ \\
\hline
\end{tabular}


680

681

682

\begin{tabular}{lcrccc}
\hline \multicolumn{1}{c}{ Location } & Status & \multicolumn{1}{c}{$L_{\infty}$} & $k$ & $t_{0}$ & Reference \\
\hline Eufaula Lake, OK & Native & 622 & 0.091 & -2.526 & Boxrucker and Kuklinski 2006 \\
Hugo Lake, OK & Native & 512 & 0.214 & -0.677 & Boxrucker and Kuklinski 2006 \\
Kaw Lake, OK & Native & 853 & 0.136 & -0.151 & Boxrucker and Kuklinski 2006 \\
Keystone Lake, OK & Native & 860 & 0.133 & -0.919 & Boxrucker and Kuklinski 2006 \\
Lake Ellsworth, OK & Native & 898 & 0.063 & -0.665 & Boxrucker and Kuklinski 2006 \\
Lake Texoma, OK & Native & 964 & 0.077 & -1.843 & Boxrucker and Kuklinski 2006 \\
Waurika Lake, OK & Native & 1050 & 0.095 & 0.114 & Boxrucker and Kuklinski 2006 \\
Ft. Loudoun Reservoir, TN & Native & 1105 & 0.044 & -1.227 & Stewart et al. 2009 \\
Kentucky Lake, TN & Native & 940 & 0.126 & -1.217 & Stewart et al. 2009 \\
Lake Barkley, TN & Native & 1115 & 0.110 & -0.693 & Stewart et al. 2009 \\
Mississippi River, TN & Native & 830 & 0.145 & -1.019 & Stewart et al. 2009 \\
Lake Wilson, AL & Native & 1303 & 0.081 & -0.243 & Holley et al. 2009 \\
Altamaha River, GA & Non-native & 745 & 0.238 & -0.367 & Bonvechio et al. 2011 \\
Badin Lake, NC & Non-native & 1028 & 0.138 & -0.239 & Dorsey et al. 2011 \\
Lake Norman, NC & Non-native & 939 & 0.094 & -0.880 & Dorsey et al. 2011 \\
\hline
\end{tabular}

TABLE 3. Blue Catfish Ictalurus furcatus populations considered in examination of range-wide growth. Parameters from the von Bertalanffy growth model $\left(L_{\infty} \mathrm{mm}, k \mathrm{yr}^{-1}\right.$, and $\left.t_{0} \mathrm{yr}\right)$ taken from listed references (or estimated from mean total length-at-age as Bonvechio et al. 2011).
683

684

685

686

687

688

689

690

691

692

TABLE 4. Model rankings using Akaike information criterion (AICc) for the von Bertalanffy growth function (Model 0) and its extension to nonlinear mixed models with random effects of river, collection year, and cohort fitted to 9,377 Blue Catfish Ictalurus furcatus total length-atage observations in four Virginia tidal rivers collected from 2002 to 2016.

\begin{tabular}{ccrr}
\hline Rank & Model & $\mathrm{AIC}_{\mathrm{c}}$ & $\Delta \mathrm{AIC}_{\mathrm{c}}$ \\
\hline 1 & Model River:Cohort & -6844.6 & 0 \\
2 & Model River:Year & -6019.9 & 824.7 \\
3 & Model Year & -3888.5 & 2956.1 \\
4 & Model River & -3621.5 & 3223.1 \\
5 & Model Cohort & -2845.6 & 3999.0 \\
6 & Model 0 & -1570.1 & 5274.5 \\
\hline
\end{tabular}

TABLE 5: Slopes and P-values from simple linear regression examining trends in length-at-age (ages 1, 4, 7, 10, and 13) over collection years (2002-2016) for Blue Catfish Ictalurus furcatus in four Virginia subestuaries of the Chesapeake Bay.

Age James $\quad$ Mattaponi Pamunkey Rapannock




\begin{tabular}{rrrrr}
\hline 1 & $-1.28, P=0.006$ & $-2.53, P<0.001$ & $-1.77, P<0.001$ & $-0.47, P=0.165$ \\
4 & $-2.04, P=0.005$ & $-2.79, P<0.001$ & $-6.34, P<0.001$ & $0.60, P=0.270$ \\
7 & $-8.47, P<0.001$ & $-11.83, P<0.001$ & $-14.70, P<0.001$ & $-3.09, P=0.026$ \\
10 & $-15.23, P<0.001$ & $-18.35, P<0.001$ & $-18.99, P<0.001$ & $-11.34, P<0.001$ \\
13 & $-15.03, P<0.001$ & $-23.30, P<0.001$ & $-26.67, P<0.001$ & $-7.49, P=0.061$ \\
\hline
\end{tabular}

693 


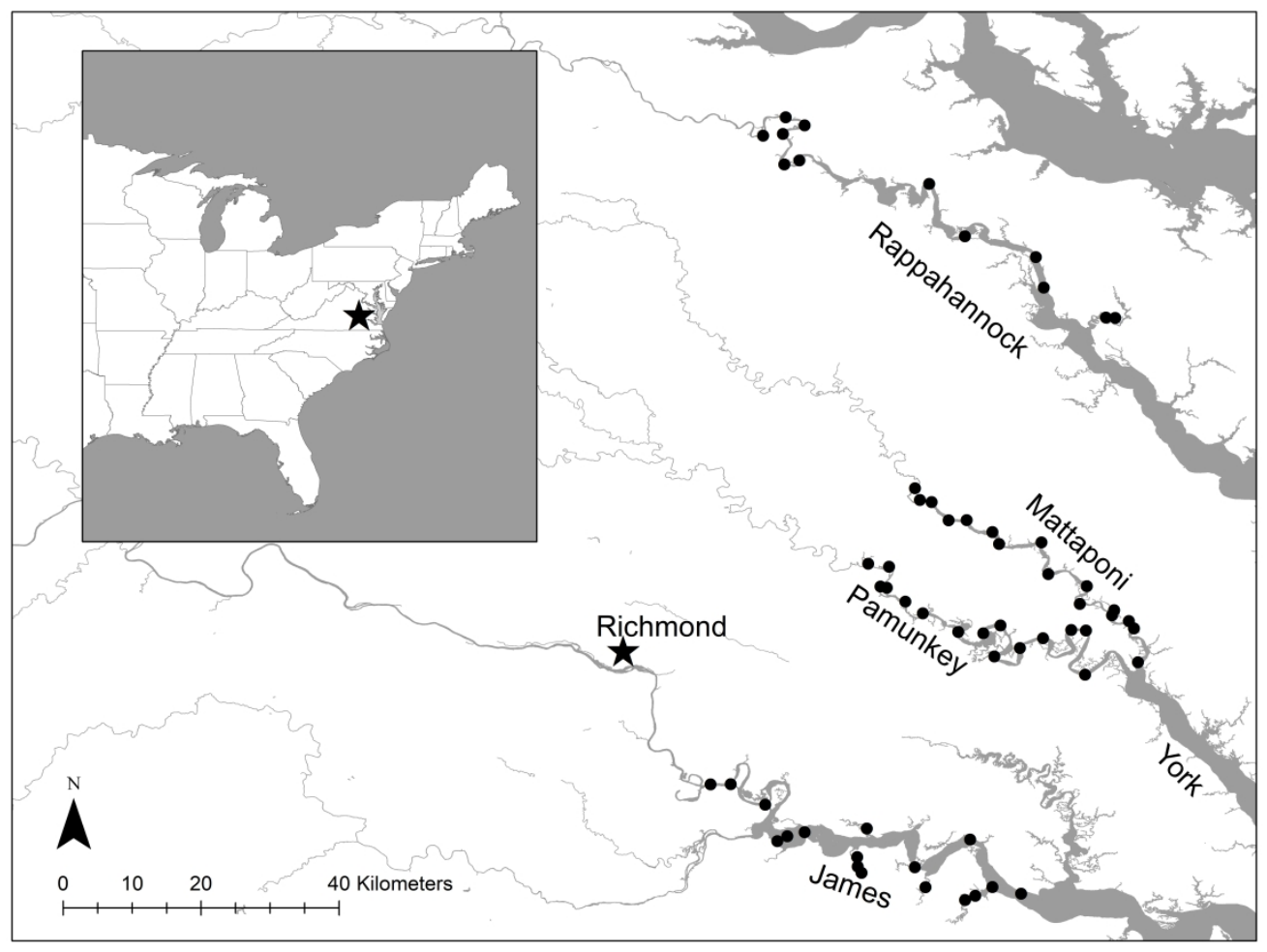

FIGURE 1. Major Chesapeake Bay tributaries in Virginia with electrofishing sites for Blue Catfish Ictalurus furcatus otolith collections (black circles) from 2002 to 2016 . The inset depicts where the study area is located in the eastern United States related to Richmond, Virginia (black star).

$304 \times 228 \mathrm{~mm}(600 \times 600 \mathrm{DPI})$ 
Hilling_et_al_Figure 2
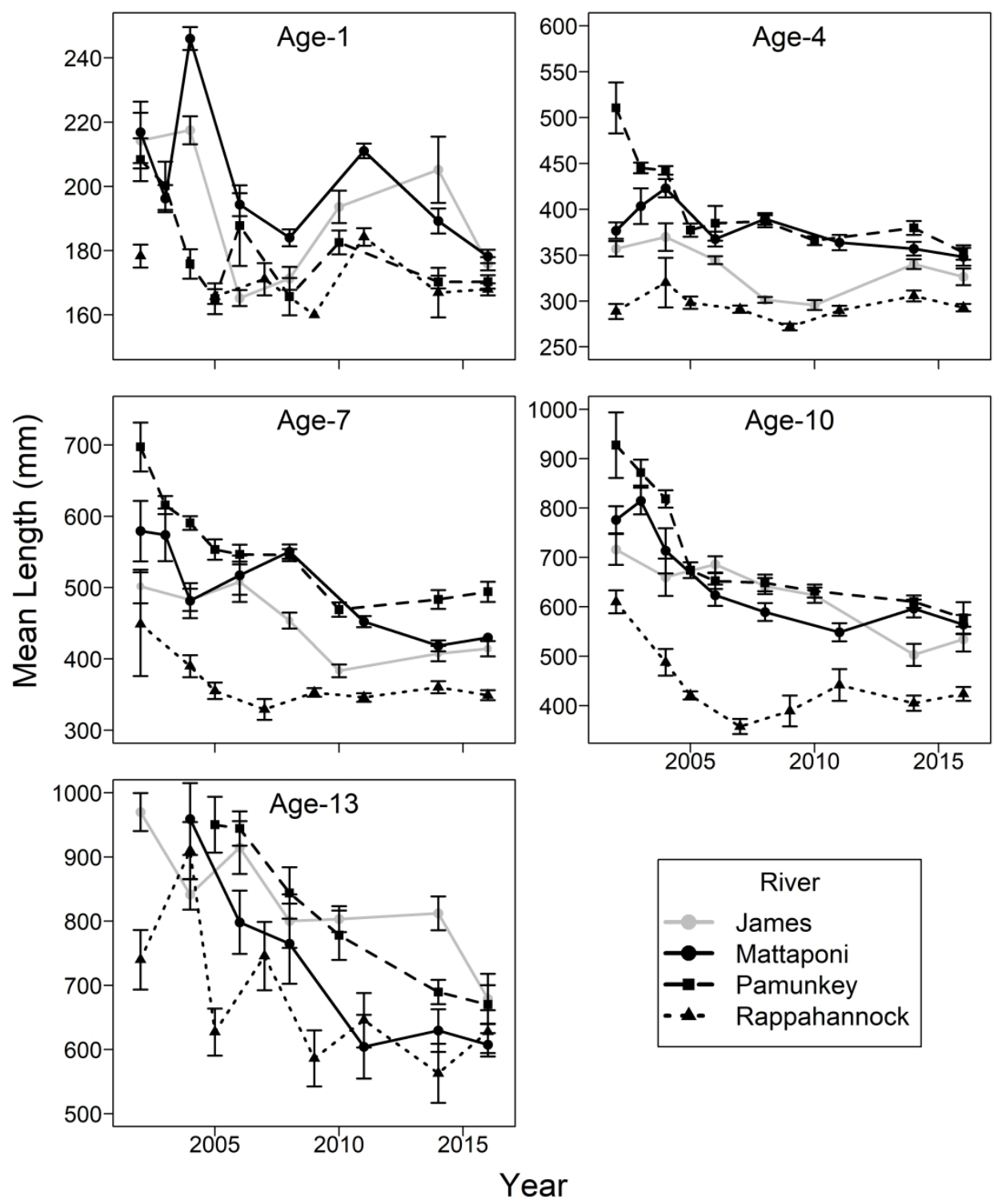

FIGURE 2. Mean total length-at-age for Blue Catfish Ictalurus furcatus collected using boat electrofishing from 2002 to 2016 in four Virginia, USA tidal rivers for ages 1, 4, 7, 10, and 13. Ages were assigned from sectioned otoliths. Error bars represent standard errors.

$190 \times 228 \mathrm{~mm}(600 \times 600 \mathrm{DPI})$ 


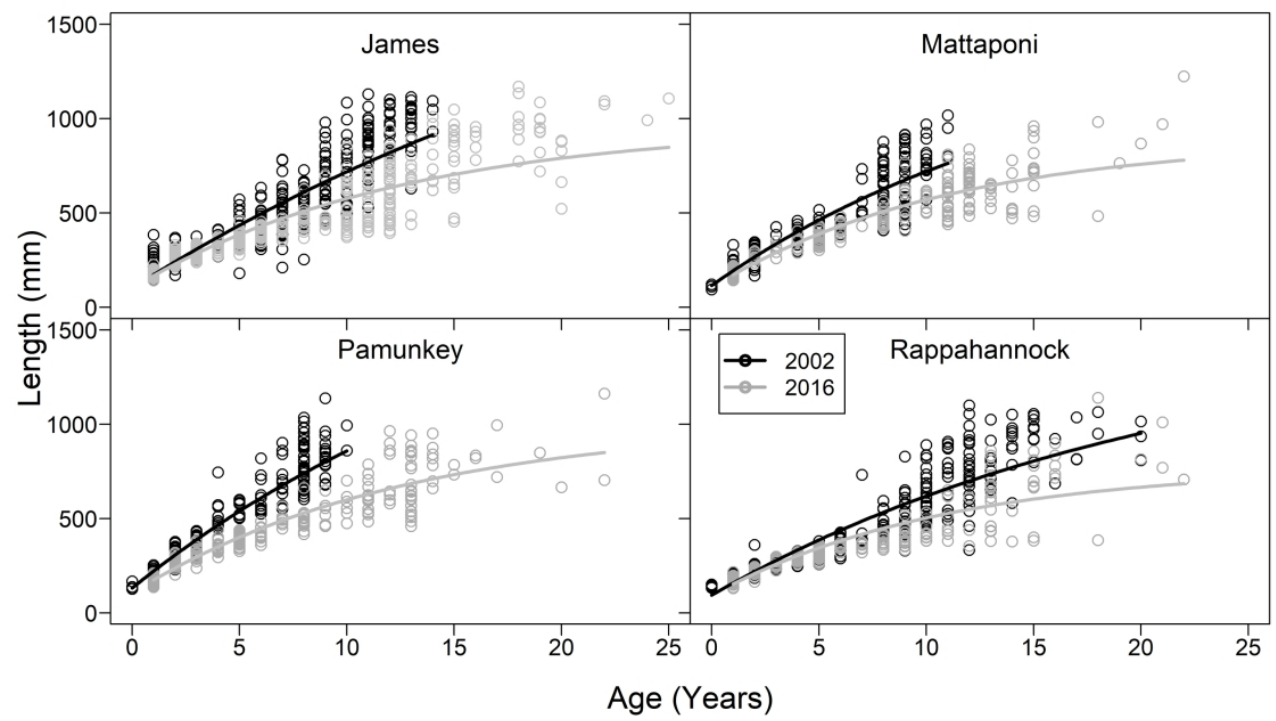

Predicted Blue Catfish Ictalurus furcatus total length-at-age (lines) and individual length-at-age observations (circles) for four Virginia, USA tidal rivers using a von Bertalanffy growth model extended to nonlinear mixed-effect model with random effects of river and year from fish collected in 2002 and 2016. Horizontal extent of lines reflects observed ages.

$247 \times 139 \mathrm{~mm}(300 \times 300 \mathrm{DPI})$ 


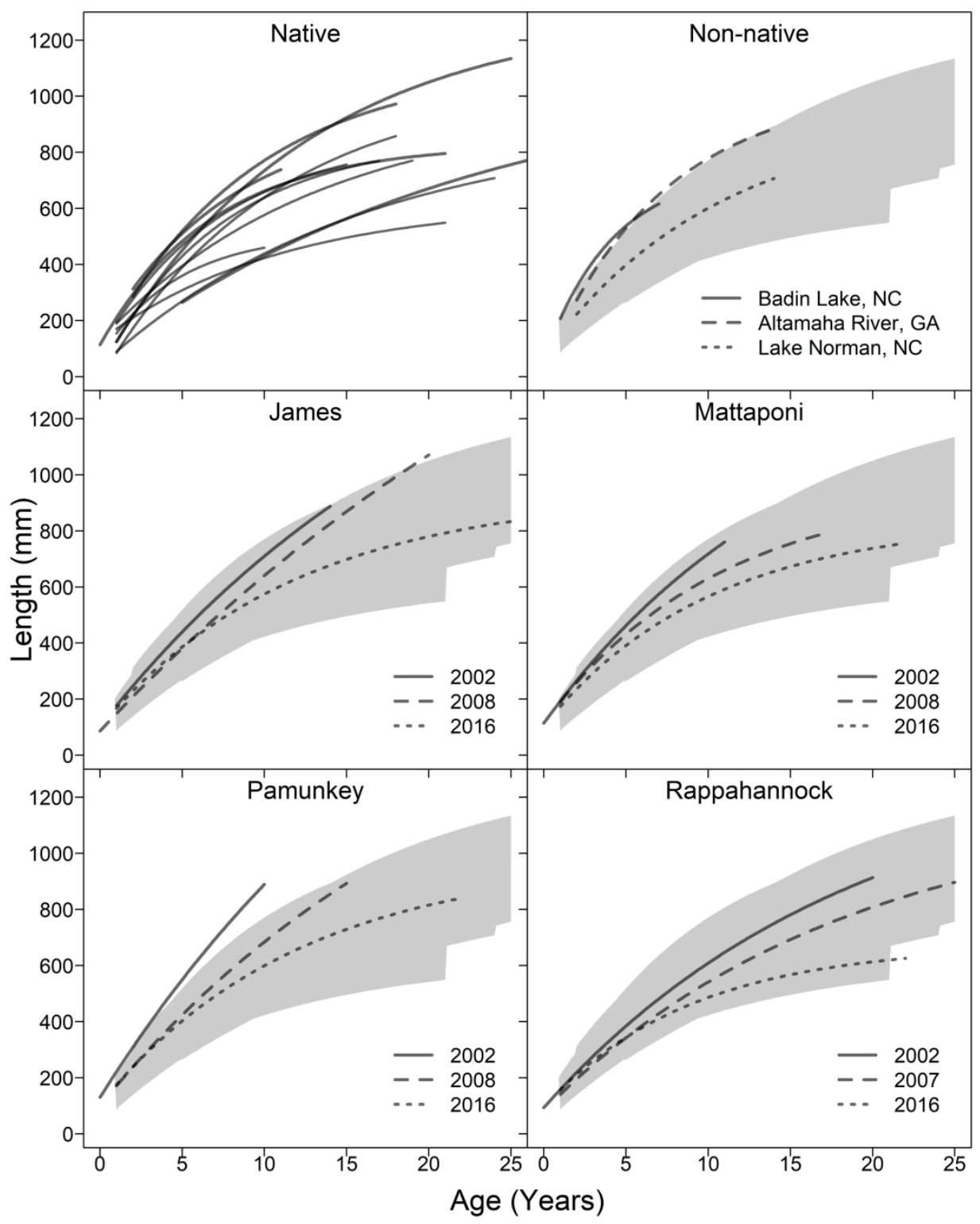

Comparison of Blue Catfish Ictalurus furcatus total length-at-age among native, non-native, and Virginia, USA non-native populations over time (James, Mattaponi, Pamunkey and Rappahannock rivers). Lines represent fitted von Bertalanffy models within the extent of observed ages. Shaded area indicates the range of fitted curves from the native populations.

$$
203 \times 254 \mathrm{~mm}(300 \times 300 \text { DPI) }
$$

